\title{
A Real World Illustration Of SFAS 158
}

Stuart Shough, University of South Carolina, USA

\begin{abstract}
This article presents an illustration of a defined benefit pension plan for an employer after having adopted SFAS 158, Employers' Accounting for Defined Benefit Pension and Other Postretirement Plans. New requirements to report the funded status of a defined benefit plan are demonstrated using journal entries and T-accounts from the beginning of a plan to its conclusion.
\end{abstract}

\section{INTRODUCTION}

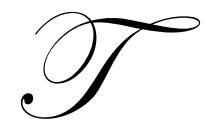

he FASB issued SFAS 158. Employers' Accounting for Defined Benefit Pension and Other Postretirement Plans in September, 2006 to address concerns that existing standards for employers' accounting for defined benefit pension plans did not adequately communicate the funded status of those plans. Prior standards did not require employers to report the funded status, overfunded when the projected benefit obligation is less than the fair value of plan assets or underfunded when the projected benefit obligation is greater than plan assets, in the statement of financial position. Issuers of publicly traded equity securities were required to adopt the statement for the fiscal year ending after December 15, 2006 and nonpublic companies had an effective date for the year ending after December 15, 2007.

SFAS 158 requires employers to report either a net liability (projected benefit obligation is greater than the fair value of pension assets) or a net asset (projected benefit obligation is less than the fair value of pension assets). Previously employers only had to report a minimum liability that resulted when accumulated benefit obligation was greater than pension assets. Instead of a company disclosing the funded status of the pension plan, SFAS 158 requires the company to record the underfunded or overfunded status, thus increasing the transparency of the financial statements. SFAS 158 did not change how pensions are accounted for and reported in the income statement, however, accounts such as prior service cost and net gain that are used in computing pension expense were previously off-balance sheet accounts, they are now listed in accumulated other comprehensive income (AOCI).

Prior to SFAS 158 the recognition of a liability (accrued pension cost) was required when the net periodic pension expense exceeded the cash payments into the plan by the employer. If cash payments exceeded the net periodic pension expense, an asset (prepaid pension cost) was recognized. In addition to the accrued/prepaid pension cost, the employer had to recognize a minimum liability if the accumulated benefit obligation exceeded the fair value of plan assets.

By adopting SFAS 158 employers will not have the accrued/prepaid pension account or the recognition of a minimum liability. Instead, a net asset will be recognized if the plan assets exceed the projected benefit obligation or a net liability will be recognized if the projected benefit obligation exceeds the plan assets, as shown in the following example.

This article will present an example of one employee (could easily be extended to combined groups of similar employees to account for all participants of a plan) enrolled in a defined benefit pension plan for a 5-year period. The calculation of the projected benefit obligation, net periodic pension expense, net pension asset/liability, and journal entries (including income taxes) will be shown and explained for a 5-year period including selected Taccounts. 


\section{EXAMPLE}

Sam Parker was hired by the ABC Company on January 1, 2008 and will retire on December 31, 2112. The company has a defined benefit pension plan that pays a lump sum upon retirement of $\$ 1,000$ for each year of service after the date of hire. On January 1, 2010, ABC Company amended the plan to pay $\$ 1,500$ for each year of service at retirement date, retroactive for one year of prior service.

Assume: The discount rate is $10 \%$. The expected and actual return on plan assets will be $10 \%$ for all years other than 2009 which is $12 \%$. In order to show income taxes, each year will have revenue of $\$ 3,000$ and no expenses other than net periodic pension expense.

Service cost is the only component of net pension expense for 2008 .

Service cost
(P.V. at $10 \%$ of $\$ 1,000$ in 4 years $=0.683013 \times \$ 1,000)$
$\$ 683.01$
Net periodic pension expense for 2008
$\$ 683.01$

Service cost is calculated by taking the present value of the future cost of benefits earned by Sam during 2008 and increases the projected benefit obligation. ABC Company contributed $\$ 700.00$ to the plan in 2008 .

\begin{tabular}{|c|c|c|c|}
\hline Date & Account Titles and Explanation & Debit & Credit \\
\hline \multirow[t]{12}{*}{2008} & Pension Expense & 683.01 & \\
\hline & Pension Asset/Liability & & 683.01 \\
\hline & To record pension expense & & \\
\hline & & & \\
\hline & Pension Asset/Liability & 700.00 & \\
\hline & Cash & & 700.00 \\
\hline & To record funding the pension plan & & \\
\hline & & & \\
\hline & Income Tax Expense & 926.80 & \\
\hline & Deferred Tax Liability & & 6.80 \\
\hline & Taxes Payable & & 920.00 \\
\hline & To record income tax expense & & \\
\hline
\end{tabular}
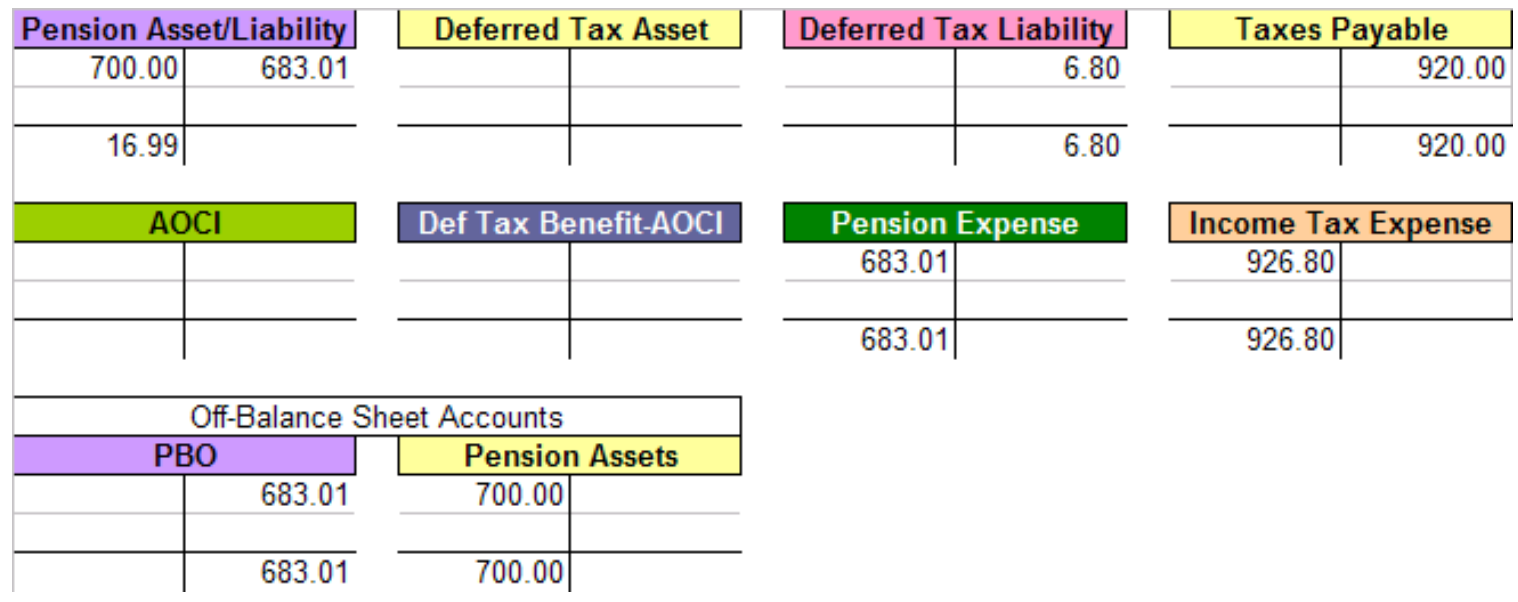
ABC Company would report a $\$ 16.99$ net pension asset as of December 31, 2008 since the pension plan is overfunded (projected benefit obligation is less than the fair value of plan assets).

Accounting income amounts to $\$ 2,316.99$ (sales $\$ 3,000.00$ - pension expense $\$ 683.01$ ) and income tax expense $\$ 926.80(\$ 2,316.99 \times 40 \%)$.

Pension expense of $\$ 683.01$ is deducted for accounting income and $\$ 700.00$ pension expense deducted for taxable income. The difference of $\$ 16.99$ multiplied by the tax rate, $40 \%$, creates a deferred tax liability of $\$ 6.80$.

Income tax expense would be shown in the income statement as current tax expense of $\$ 920.00$ and deferred tax expense of $\$ 6.80$.

The detail of accounting income and income tax expense for subsequent years will not be shown, but would be calculated as shown for 2008 .

The components of net pension expense for 2009 are as follows:

Service cost

P.V. at $10 \%$ of $\$ 1,000$ in 3 years $=0.751315 \times \$ 1,000 \quad \$ 751.31$

Interest cost on the beginning balance of PBO

$\begin{array}{ll}10 \% \text { x } \$ 683.01 & 68.30\end{array}$

Expected return on plan assets

$10 \%$ x $\$ 700.00$

Net periodic pension expense for 2009

$\$ 749.61$

\begin{tabular}{|c|c|c|c|}
\hline Date & Account Titles and Explanation & Debit & Credit \\
\hline \multirow[t]{18}{*}{2009} & Pension Expense & 749.61 & \\
\hline & Pension Asset/Liability & & 749.61 \\
\hline & To record pension expense & & \\
\hline & & & \\
\hline & Pension Asset/Liability & 14.00 & \\
\hline & Deferred Tax Benefit-AOCl & 5.60 & \\
\hline & $\mathrm{AOCl}$ - Net Gain & & 14.00 \\
\hline & Deferred Tax Asset & & 5.60 \\
\hline & To record unexpected gain from plan assets & & \\
\hline & Pension Asset/Liability & 700.00 & \\
\hline & Cash & & 700.00 \\
\hline & To record funding the pension plan & & \\
\hline & & & \\
\hline & Income Tax Expense & 900.16 & \\
\hline & Deferred Tax Liability & 6.80 & \\
\hline & Deferred Tax Asset & 13.04 & \\
\hline & Taxes Payable & & 920.00 \\
\hline & To record income tax expense & & \\
\hline
\end{tabular}




\begin{tabular}{|r|r|}
\multicolumn{2}{|c|}{ Pension Asset/Liability } \\
\hline 16.99 & \\
\hline 700.00 & 749.61 \\
\hline 14.00 & \\
\hline & 18.62 \\
\hline
\end{tabular}

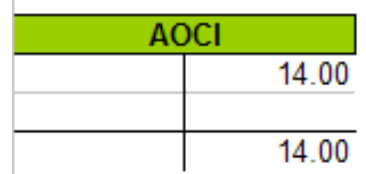

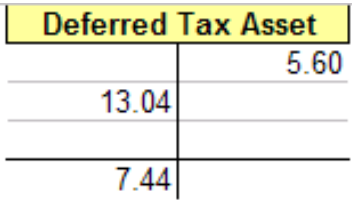
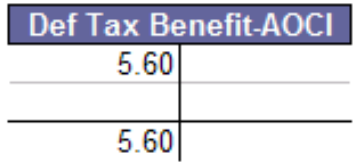

Off-Balance Sheet Accounts

\begin{tabular}{r|r}
\hline \multicolumn{2}{|c|}{ Pension Assets } \\
\hline 700.00 & \\
84.00 & \\
\hline 700.00 & \\
\hline $1,484.00$ &
\end{tabular}
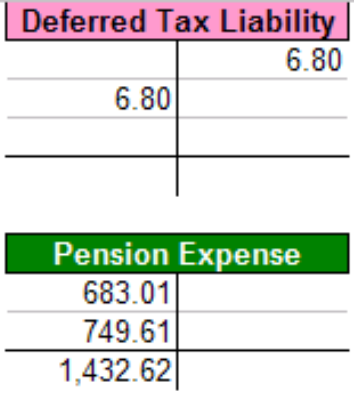
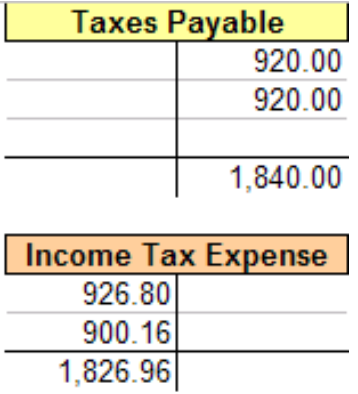

ABC Company would report a $\$ 18.62$ net pension liability in the 2009 balance sheet since the pension plan is underfunded (projected benefit obligation is greater than the fair value of plan assets).

The actual return on plan assets was $\$ 84.00$ (12\% x $\$ 700.00$, the beginning balance of plan assets) and the expected return was $\$ 70.00$ resulting in an unexpected gain of $\$ 14.00$. Gains and losses from the return on plans assets that are higher or lower than expected gains and losses are deferred and not included in pension expense for the current year. The unexpected gain on plan assets would be reported as other comprehensive income in the comprehensive income statement and included in the total of accumulated other comprehensive income in the balance sheet.

In accordance with SFAS 87, if a net gain or net loss balance at the beginning of the year exceeds the higher of $10 \%$ of the projected benefit obligation or $10 \%$ of the plan assets, the excess is divided by the average remaining service period of active employees and included in pension expense for the period.

Interest cost is the increase in the projected benefit obligation due to the passage of time. Sam Parker is one year closer to retirement at the end of 2009.

The components of net pension expense for 2010 are as follows:

Service cost

P.V. at $10 \%$ of $\$ 1,500$ in 2 years $=0.826446 \times \$ 1,500$

$\$ 1,239.67$

Interest cost on the beginning balance of PBO

$10 \%$ x $(\$ 1,502.62+\$ 375.66)$

Expected return on plan assets

$10 \%$ x $\$ 1,484.00$

Amortization of prior service cost (\$375.66 / 3)

Net periodic pension expense for 2010

$\$ 1,404.32$

ABC Company amended the plan to pay $\$ 1,500$ for each year of service at retirement date, retroactive for one year of prior service at the beginning of 2010. This will require an entry in the amount of $\$ 375.66$ (P.V. at $10 \%$ of $\$ 500.00$ in 3 years $=0.751315 \times \$ 500.00)$ to record the prior service cost for 2009 . An increase in prior service cost also increases the projected benefit obligation and pension asset/liability. In addition, the increase of prior service cost would be reported as other comprehensive income in the comprehensive income statement and included in the total of accumulated other comprehensive income in the balance sheet. 
Interest cost for 2010 is based on the beginning balance of the projected benefit obligation plus the addition of prior service cost.

Amortization of prior service cost is included in pension expense and is calculated by dividing the prior service cost by the average remaining service life of the employees. The amortization of prior service cost would be reported as other comprehensive income in the comprehensive income statement and included in the total of accumulated other comprehensive income in the balance sheet.

\begin{tabular}{|c|c|c|c|}
\hline Date & Account Titles and Explanation & Debit & Credit \\
\hline \multirow[t]{24}{*}{2010} & $\mathrm{AOCl}$ - Prior Service Cost & 375.66 & \\
\hline & Deferred Tax Asset & 150.26 & \\
\hline & Pension Asset/Liability & & 375.66 \\
\hline & Deferred Tax Benefit-AOCl & & 150.26 \\
\hline & To record prior service cost for plan amendment & & \\
\hline & & & \\
\hline & Pension Expense & $1,279,10$ & \\
\hline & Pension Asset/Liability & & $1,279.10$ \\
\hline & To record pension expense & & \\
\hline & & & \\
\hline & Pension Expense & 125.22 & \\
\hline & Deferred Tax Benefit-AOCl & 50.09 & \\
\hline & $\mathrm{AOCl}$ - Prior Service Cost & & 125.22 \\
\hline & Deferred Tax Asset & & 50.09 \\
\hline & To record amortization of prior service cost & & \\
\hline & & & \\
\hline & Pension Asset/Liability & $1,500.00$ & \\
\hline & Cash & & $1,500.00$ \\
\hline & To record funding the pension plan & & \\
\hline & & & \\
\hline & Income Tax Expense & 638.27 & \\
\hline & Deferred Tax Asset & & 38.27 \\
\hline & Taxes Payable & & 600.00 \\
\hline & To record income tax expense & & \\
\hline
\end{tabular}

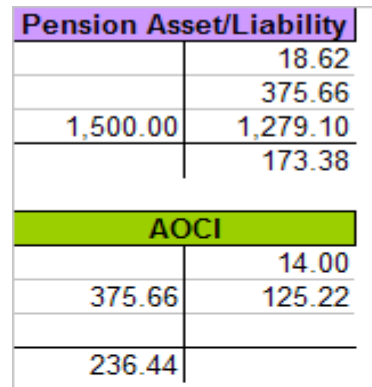

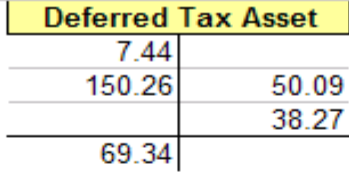

\section{Def Tax Benefit-AOCI} 5.60

\begin{tabular}{l}
50.09 \\
\hline
\end{tabular}

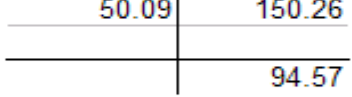

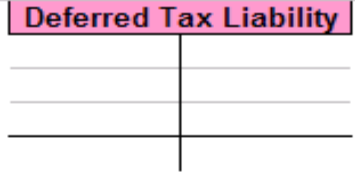

Pension Expense

$1,432.62$

$1,279.10$

125.22

$2,836.94$
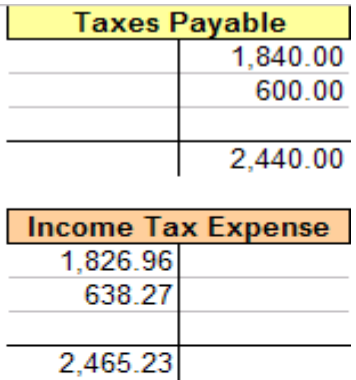

\begin{tabular}{|c|c|c|}
\hline \multicolumn{3}{|c|}{ Off-Balance Sheet Accounts } \\
\hline PBO & Pensior & Assets \\
\hline $1,502.62$ & $1,484.00$ & \\
\hline 375.66 & 148.40 & \\
\hline 187.83 & $1,500.00$ & \\
\hline $1,239.67$ & & \\
\hline $3,305,78$ & $3,132.40$ & \\
\hline
\end{tabular}

ABC Company would report a $\$ 173.38$ net pension liability in the 2010 balance sheet since the pension plan is underfunded (projected benefit obligation is greater than the fair value of plan assets). 
The components of net pension expense for 2011 are as follows:

Service cost

P.V. at $10 \%$ of $\$ 1,500$ in 1 year $=0.909091 \times \$ 1,500$

Interest cost on the beginning balance of PBO

$10 \%$ x $\$ 3,305.78$

$\$ 1,363.64$

Expected return on plan assets

$10 \%$ x $\$ 3,132.40$

Amortization of prior service cost $(\$ 375.66 / 3)$

330.58

(313.24)

125.22

Net periodic pension expense for 2011

$\$ 1,506.20$

\begin{tabular}{|c|c|c|c|}
\hline Date & Account Titles and Explanation & Debit & Credit \\
\hline \multirow[t]{18}{*}{2011} & Pension Expense & $1,380,98$ & \\
\hline & Pension Asset/Liability & & $1,380,98$ \\
\hline & To record pension expense & & \\
\hline & & & \\
\hline & Pension Expense & 125.22 & \\
\hline & Deferred Tax Benefit-AOCl & 50.09 & \\
\hline & $\mathrm{AOCl}-$ Prior Service Cost & & 125.22 \\
\hline & Deferred Tax Asset & & 50.09 \\
\hline & To record amortization of prior service cost & & \\
\hline & & & \\
\hline & Pension Asset/Liability & $1,500.00$ & \\
\hline & Cash & & $1,500.00$ \\
\hline & To record funding the pension plan & & \\
\hline & & & \\
\hline & Income Tax Expense & 597.52 & \\
\hline & Deferred Tax Asset & 2.48 & \\
\hline & Taxes Payable & & 600.00 \\
\hline & To record income tax expense & & \\
\hline
\end{tabular}

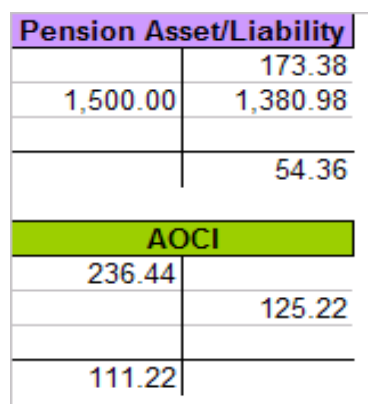

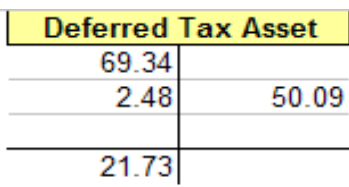
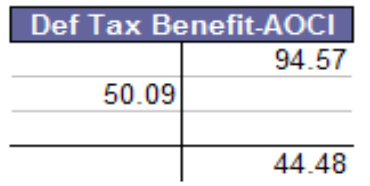

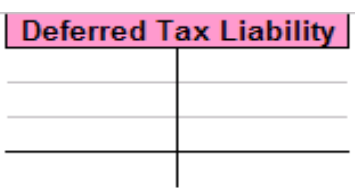

Pension Expense

2,836.94

$1,380.98$

125.22

$4,343.14$
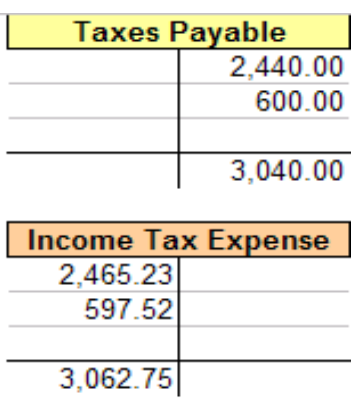
ABC Company would report a $\$ 54.36$ net pension liability in the 2011 balance sheet since the pension plan is underfunded (projected benefit obligation is greater than the fair value of plan assets).

The components of net pension expense for 2012 are as follows:

Service Cost

$\$ 1,500.00$

Interest cost on the beginning balance of PBO

$10 \%$ x $\$ 5,000.00$

500.00

Expected return on plan assets

$10 \%$ x $\$ 4,945.64$

(494.56)

125.22

Amortization of prior service cost $(\$ 375.66$ / 3)

(14.00)

Net periodic pension expense for 2012

$\$ 1,616.66$

\begin{tabular}{|c|c|c|c|}
\hline Date & Account Titles and Explanation & Debit & Credit \\
\hline \multirow{24}{*}{2012} & Pension Expense & $1,505.44$ & \\
\hline & Pension Asset/Liability & & $1,505.44$ \\
\hline & To record pension expense & & \\
\hline & & & \\
\hline & Pension Expense & 125.22 & \\
\hline & Deferred Tax Benefit-AOCl & 50.09 & \\
\hline & $\mathrm{AOCl}-$ Prior Service Cost & & 125.22 \\
\hline & Deferred Tax Asset & & 50.09 \\
\hline & To record amortization of prior service cost & & \\
\hline & & & \\
\hline & AOCl-Prior Service Cost & 14.00 & \\
\hline & Deferred Tax Asset & 5.60 & \\
\hline & Pension Expense & & 14.00 \\
\hline & Deferred Tax Benefit-AOCI & & 5.60 \\
\hline & To record amortization of prior service cost & & \\
\hline & & & \\
\hline & Pension Asset/Liability & $1,559.80$ & \\
\hline & Cash & & $1,559.80$ \\
\hline & To record funding the pension plan & & \\
\hline & & & \\
\hline & Income Tax Expense & 553.34 & \\
\hline & Deferred Tax Asset & 22.74 & \\
\hline & Taxes Payable & & 576.08 \\
\hline & To record income tax expense & & \\
\hline
\end{tabular}



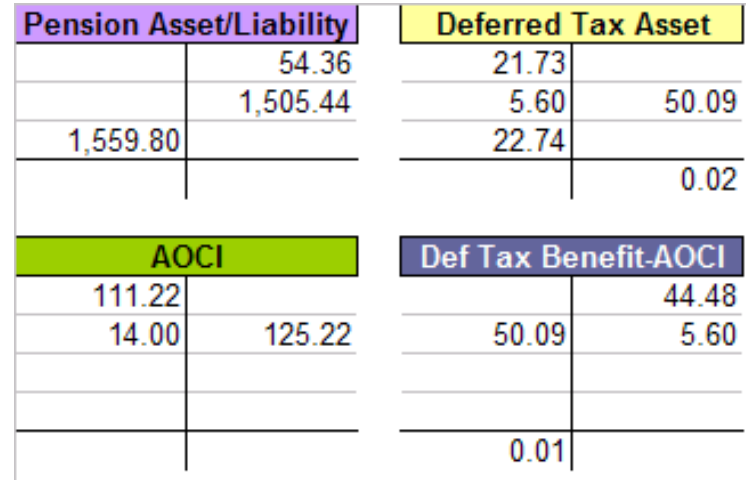

\section{Def Tax Benefit-AOCI}
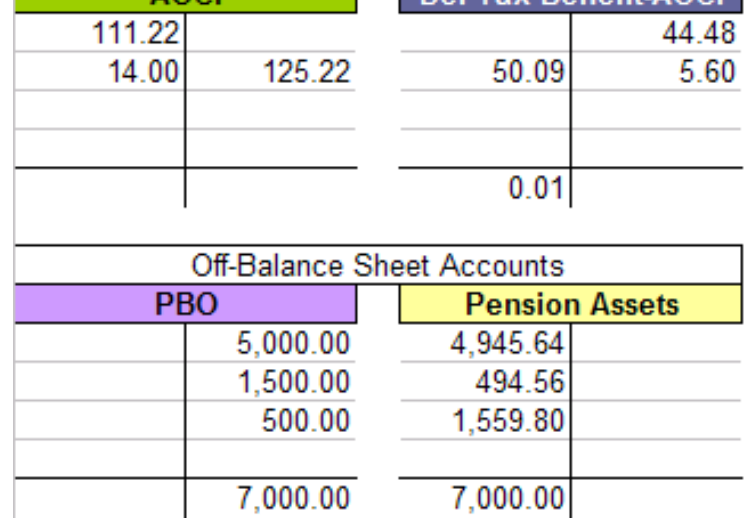

\begin{tabular}{r|r|}
\hline Pension Assets \\
\hline $4,945.64$ & \\
\hline 494.56 & \\
\hline $1,559.80$ & \\
\hline & \\
\hline $7,000.00$ &
\end{tabular}
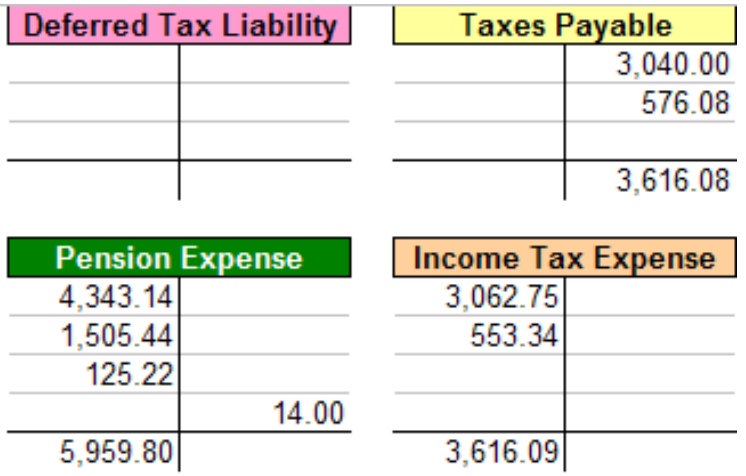

Rounding errors have not been corrected with the 2012 entries.

\section{SUMMARY}

\begin{tabular}{|c|c|c|c|}
\hline Year & $\begin{array}{l}\text { Pension } \\
\text { Expense }\end{array}$ & $\begin{array}{l}\text { Return on } \\
\text { Plan Assets }\end{array}$ & $\begin{array}{c}\text { Cash } \\
\text { Pavments }\end{array}$ \\
\hline 2008 & $\$ 683.01$ & $\$$ & $\$ 700.00$ \\
\hline 2009 & 749.61 & 84.00 & 700.00 \\
\hline 2010 & $1,404.32$ & 148.40 & $1,500.00$ \\
\hline 2011 & $1,506.20$ & 313.24 & $1,500.00$ \\
\hline 2012 & $1,616.66$ & 494.56 & $1,559.80$ \\
\hline Totals & $\$ 5,959.80$ & $\overline{\$ 1,040.20}$ & $\$ 5,959.80$ \\
\hline
\end{tabular}

On December 31, 2012, both off-balance sheet accounts, PBO and Pension Assets have a $\$ 7,000$ balance. The return on plan assets plus cash payments equal \$7,000.00, the amount of the pension benefit owed to Sam Parker. Both net income and comprehensive income for the 5-year period equal $\$ 6,034.32$ (recall revenue of $\$ 3,000.00$ each year and pension expense as the only expense each year). 